Biotechnology Research

http:/www.journals.zu.edu.eg/journalDisplay.aspx?Journalld=1\&queryType=Master

\title{
ANTIMICROBIAL ACTIVITY OF LECTIN ISOLATED FROM EGYPTIAN WHEAT CULTIVAR GIZA 171
}

\author{
Safa A. Mostafa ", H.A. Badr, A. Osman and K.M. Wahdan \\ Agric. Biochm. Dept., Fac. Agric., Zagazig Univ., Egypt
}

Received: 10/04/2019 ; Accepted: 12/05/2019

\begin{abstract}
In the current study crude lectin was isolated from Egyptian wheat seeds cultivar Giza 171 and it was characterized by several methods such as sodium dodecyl sulfate-polyacrylamide gel electrophoresis (SDS-PAGE), Native-PAGE, Iso-electric point evaluation, Fourier transform infrared (FTIR) spectroscopy and amino acids composition. Furthermore, antibacterial and antifungal activities were estimated against some gram positive, gram negative bacteria and pathogenic fungus. Based on Native-PAGE (unreduced) of wheat seeds lectin indicates one major band with a molecular weight of approximately $50 \mathrm{kDa}$. SDS-PAGE of wheat seeds lectin separated this high molecular weight band into 2 bands corresponding to smaller molecular weights $(14,20 \mathrm{kDa})$. The iso-electric points were deduced from the protein $\mathrm{pH}$-solubility curve. It is clear that the least soluble points were obtained at $\mathrm{pH}$ 5.5. The content of the hydrophobic amino acids residues (proline, valine, isoleucine, leucine and phenyl alanine) valued $27.8 \%$ and this represent $31.1 \%$ of the total amino acids. The minimum inhibitory concentrations (MIC) of lectin against $L$. monocytogenes and $P$. aeruginosa was $800 \mu \mathrm{g} / \mathrm{ml}, 1600 \mu \mathrm{g} / \mathrm{ml}$ for $B$. subtillis and $3200 \mu \mathrm{g} / \mathrm{ml}$ against E. coli. Lectin inhibited mycelial growth of $F$. oxysporun and $F$. solani at a wide concentration range $(250,500$ and $1000 \mu \mathrm{g} / \mathrm{ml})$. This study has elucidated that the lectin isolated from wheat seeds cultivar Giza 171 have the potent antibacterial and antifungal activities against selected pathogenic bacteria and fungai.
\end{abstract}

Key words: Wheat, lectin, antibacterial, antifungal, SDS-PAGE.

\section{INTRODUCTION}

Lectins are members of a superfamily of proteins that express the capacity to bind to specific carbohydrates reversibly without altering their covalent structure. Common dietary staples, such as cereal grains, legumes, and fruits have relatively high concentrations of a variety of lectins. Especially black beans, soybeans, kidney beans, and (whole) grains are known for significant quantities of different lectins (Matucci et al., 2004). In nature, lectins play a role in biological recognition phenomena involving cells and proteins and hereby protect plants against external pathogens such as fungi and other organisms (van Buul and Brouns, 2014). There are at least three reasons for the need to finding out new alternative antimicrobial substances from natural sources. The first reason is that people nowadays concern about toxic of synthetic substances including daily contact chemicals or even drugs used in medical or healthcare purposes (Hafidh et al., 2009). Any synthetic drugs were avoided in order to keep physiological cleans as belief. Thus, natural substances were used increasingly instead as well as any drugs used for antimicrobial purposes. The second reason is that new alternative drugs are human hope for better fighting with existed diseases and pathogens. They may replace currently used drugs in points of more efficiency, more abundant, lower side-effect or safer or even lower production cost. It is a fact that most alive organisms should have some mechanisms or substances fight with all-time contacting pathogens so that they can be survived in nature. Although plenty of antibiotics were discovered after first time Fleming's declaration, they were still relatively low amounts

\footnotetext{
*Corresponding author: Tel. : +2001013612760

E-mail address: Safa.abdo903@gmail.com
} 
compared with overall real natural antimicrobial substances. This means the natural sources still flourish with novel antimicrobial substances waiting for discovered. Additional small aspect may be raised here. The natural substances are usually good leading compound sources for the mostly synthetic drug from the long past due to their diversities are far from human imagination. New chemical structures are always found in natural resources as higher frequency than artificial deducing structures. The final reason is that the mechanism used to synthesize natural substances are available and they are usually can be imitated in small, medium, and even large scale production with present biotechnological knowledge which looks easier than newly designed plants (Karnchanatat, 2012). Natural antioxidants may have free-radical scavengers, reducing agents, complexes of prooxidant metals, quenchers of singlet oxygen, etc. Recently research has been increased considerably in finding natural occurring antioxidants for use in foods or medical products to replace synthetic antioxidants, which are being restricted due to their adverse reaction such as carcinogenicity. Where cancer is the leading cause of morbidity and mortality around the world, with approximately 14 million new cases and 8.2 million cancer related deaths worldwide in 2012 (Siegel et al., 2014). Furthermore, the number of new cases in developed countries is expected to rise up to $70 \%$ in the next decades (Siegel et al., 2014), due to population ageing and growth (Thorburn, 2008). Hence there is a need for discovery of new anticancer drugs, especially those with novel mechanisms of action that can combat resistance. The present study reports the isolation, purification, characterization, and evaluation of the antibacterial, antifungal, of a lectin isolated from Egyptian wheat cultivar Giza 171.

\section{MATERIALS AND METHODS}

\section{Plant Material}

The wheat seeds, cultivar Giza 171 were obtained from Agricultural Research Centre, Ministry of Agricultural, Giza, Egypt, for isolation and purification of lectin.

\section{Crue Lectin Isolation}

The seeds of wheat were ground and extracted overnight at $4^{\circ} \mathrm{C}$ in $0.01 \mathrm{M}$ phosphate buffered saline (PBS) $\mathrm{pH}$ 7.2, followed by centrifugation at $3000 \mathrm{~g}$ at $4^{\circ} \mathrm{C}$ for $10 \mathrm{~min}$. Solid $\left(\mathrm{NH}_{4}\right)_{2} \mathrm{SO}_{4}$ was added to the obtained supernatant up to $60 \%$ saturation and the proteins were precipitated at $4^{\circ} \mathrm{C}$ overnight. The precipitated proteins were centrifuged at $12,000 \mathrm{~g}$ at $4^{\circ} \mathrm{C}$ for $15 \mathrm{~min}$, and then dissolved in PBS, followed by dialysis against PBS until.

\section{Native PAGE}

Protein samples were dissolved $(5 \mathrm{mg} / \mathrm{ml})$ in a buffer (pH 6.8) containing $0.25 \mathrm{M}$ Tris base and $50 \%$ glycerol and analyzed by native PAGE according to Laemmli (1970) in 3 and $8 \%$ acrylamide for the stacking and resolving gels, respectively. The electrode buffer $(\mathrm{pH} \mathrm{8.3)}$ was composed of $0.125 \mathrm{M}$ Tris base and $0.96 \mathrm{M}$ glycine.

\section{SDS-PAGE}

An amount of wheat seeds lectin $(20 \mathrm{mg})$ was dispersed in $1 \mathrm{ml}$ SDS $10 \%$ with $100 \mu \mathrm{l} \beta$ mercaptoethanol for $15 \mathrm{~min}$ with vortexing every $5 \mathrm{~min}$. The extract was centrifuged at $11,000 \mathrm{~g}$ for $10 \mathrm{~min}$. A mixture of $20 \mu \mathrm{l}$ extract and $20 \mu \mathrm{l}$ of SDS-loading sample buffer (SDS $4 \%$, $\beta$-mercaptoethanol $3 \%$, glycerol $20 \%$, Tris $\mathrm{HCl} 50 \mathrm{mM}$ pH 6.8 and bromophenol blue traces), was heated at $96^{\circ} \mathrm{C}$ for $3 \mathrm{~min}$ and $10 \mu \mathrm{l}$ aliquot (per lane) was electrophoresed by SDSPAGE according to Laemmli (1970).

\section{Iso-electric Point (protein pH-solubility curves)}

The iso-electric points were deduced from the protein $\mathrm{pH}$-solubility curves as the $\mathrm{pH}$ at which the protein is less soluble. Protein $\mathrm{pH}$ solubility curves were assayed in the $\mathrm{pH}$ range of 2-10 according to the procedure outlined by Chobert et al. (1991) with some modification. One hundred and twenty-five milligrams of each sample was dispersed in $25 \mathrm{ml}$ of distilled water and the solution $\mathrm{pH}$ was adjusted to 2-10 using either $0.5 \mathrm{~mol} / 1 \mathrm{NaOH}$ or $0.5 \mathrm{~mol} / 1 \mathrm{HCl}$. The slurries were mixed for $1 \mathrm{hr}$., at $30^{\circ} \mathrm{C}$ using magnetic bar before centrifuging at $1200 \mathrm{~g}$ for $20 \mathrm{~min}$ at $4^{\circ} \mathrm{C}$. The supernatant was filtered to obtain a clear solution. Protein content in the supernatant was determined by Kjeldahl method (Horwitz and Latimer, 2000). Triplicate determinations were carried out and the solubility profile was obtained by plotting averages of protein solubility (\%) against $\mathrm{pH}$ : 
Solubility $(\%)=$ Amount of protein in the supernatant $\div$ amount of protein in the sample $\times 100$

\section{Amino Acid Composition}

The composition of amino acids for lectin isolated from wheat seeds was evaluated according to Simpson et al. (1976) by amino acid analyzer instrument model "Eppendorf LC3000" using the following procedure: $0.2 \mathrm{~g}$ from lectin isolated from wheat seeds received $10 \mathrm{ml} \mathrm{HCl}(6 \mathrm{~N})$ in a sealing tube, and then put in oven at $110^{\circ} \mathrm{C}$ for $24 \mathrm{hr}$. Hydrolysates were transported quantitatively into a porcelain dish and $\mathrm{HCl}$ was evaporated to dryness at $50-60^{\circ} \mathrm{C}$ on a water bath. To remove the excess of hydrochloric acid, $5 \mathrm{ml}$ distilled water was added to the hydrolysates and evaporated to dryness. Finally, the remains was dissolved in $10 \mathrm{ml}$ distilled water and filtrate through filter membrane $(0.45 \mu \mathrm{m})$. The filtrate was lyophilized then 10 $\mathrm{ml}$ of distilled water were added and the samples lyophilized a second time. One $\mathrm{ml}$ of sodium citrate buffer $0.2 \mathrm{~N}$ at $\mathrm{pH} 2.2$ was added and the samples stocked frozen in a closed vial until amino acids separation by amino acid analyzer (Column: hydrolysate column Eppendorf LC $3000(250 \times 4.6)$. Its temperature is $47^{\circ} \mathrm{C}$; Sample: $30 \mu \mathrm{l}$; Buffer system: buffer A: Sodium acetate $\mathrm{pH}$ 3.3, buffer B Sodium acetate $\mathrm{pH} 3.6$, buffer C: Sodium acetate $\mathrm{pH} 4.3$ and buffer D: Sodium acetate $\mathrm{pH} 11.0$; Flow rate: $0.3 \mathrm{ml} / \mathrm{min}$.). Ninhydrin is utilized for the revelation of amino acids at $440 \mathrm{~nm}$ for proline and $570 \mathrm{~nm}$ for the other amino acids out of an oxidative decarboxylation reaction. The peak zone and percentage of each amino acid were determinated by computer software AXXIOM CHROMATOGRAPHY- 727.

\section{Fourier Transform Infrared (FTIR) Spectroscopy}

Lectin isolated from wheat seeds was prepared with potassium bromide $(\mathrm{KBr})$ pellet method according the study of Souillac et al. (2002). Infrared spectra was measured with a FT-IR spectrometer (NICOLET NEXUS 470, DTGS, Thermo Scientific, Waltham, MS, USA) at $25^{\circ} \mathrm{Cat}$ National Research Center (NRC), Giza, Egypt. For each spectrum 256 interferograms were collected with a resolution of $4 \mathrm{~cm}-1$ with 64 scans and a $2 \mathrm{~cm}$ interval from the 4000 to $400 \mathrm{~cm}^{-1}$ region. The system was continuously purged with dry air. Second derivation spectra were obtained with SavitskyGolay derivative function soft as followed by Surewicz and Mantsch (1988).

\section{Antibacterial Activity}

Two gram positive bacteria (Listeria monocytogenes and Bacillus subtilis) and two gram negative bacteria (Pseudomonas aeruginosa and Escherichia coli) were kindly gained from the Laboratory of Microbiology, Department of Microbiology, Faculty of Science, Zagazig University, Egypt. Wheat seeds lectin was tested for antibacterial activity at different concentrations $(0,200,400,800,1600,3200$ and $6400 \mu \mathrm{g} / \mathrm{ml})$ against two gram positive bacteria and two gram negative bacteria by conventional well-diffusion assay (Nanda and Saravanan, 2009). The clear cultures of bacterial strains were sub-cultured on nutrient broth at $37^{\circ} \mathrm{C}$ on a rotary shaker at 200 $\mathrm{rpm}$. Every strain was dispersal uniformly onto the single plates using sterile cotton swabs. Wells of 6-mm diameter were made on Müller Hinton Agar (MHA) plates using a gel puncturing tool. Forty $\mu 1$ of each concentration $(0,200,400$, $800,1600,3200$ and $6400 \mu \mathrm{g} / \mathrm{ml})$ were carried into each well. After incubation at $37^{\circ} \mathrm{C}$ for 24 hr., the diameter of the inhibition zone was recorded by using a ruler. Minimum inhibitory concentration (MIC) of lectin was estimated as recorded earlier (Abdel-Hamid et al., 2016). The lowest concentration of the examined articles that presented visible clear zone on MuellerHinton agar plates was regarded as the minimal inhibitory concentration.

\section{Antifungal Activity}

The effect of the lectin isolated from wheat seeds on the mycelial growth of Fusarium oxysporum and Fusarium solani was evaluated also at different concentrations $(250,500$ and $1000 \mu \mathrm{g} / \mathrm{ml}$ ) using the poisoned food technique (Yahyazadeh et al., 2009). A $6 \mathrm{~mm}$ mycelial agar plug from a 7-day-old culture of Fusarium oxysporum or Fusarium solani was placed at the center of each Potato dextrose agar (PDA) plate and calculated volumes of the tested substances were added, to achieve the previously mentioned concentrations. Approximately, 0.05\% ( $V / V)$ Tween- 80 was then added to the media. Petri dishes were sealed with parafilm and incubated for 7 dayes at $25^{\circ} \mathrm{C}$. The diameter $(\mathrm{mm})$ of colony zone was measured with a caliper. 


\section{RESULTS AND DISCUSSION}

\section{Chemical Characterization}

\section{Native-PAGE and SDS-PAGE}

The Native-PAGE (unreduced) of wheat seeds lectin indicates one major band with a molecular weight of approximately $50 \mathrm{kDa}$, confirming its chemical identity (Fig. 1). SDSPAGE (reduced with $\beta$-mercapto-ethanol) of wheat seeds lectin (Fig. 1) separated this high molecular weight band into 2 bands corresponding to smaller molecular weights $(14,20 \mathrm{kDa})$.

\section{Iso-electric point}

The iso-electric points were deduced from the protein $\mathrm{pH}$-solubility curve as the $\mathrm{pH}$ at which the protein is less soluble. The $\mathrm{pH}$ solubility curve of lectin isolated from wheat seeds is given in Fig. 2. It is clear that the least soluble points were obtained at $\mathrm{pH} 5.5$. These results agree with those reported by MendozaBlanco et al. (2012).

\section{Amino acids analysis}

As shown in Table 1 the amino acid composition of the crude lectin is typified by high concentrations of glutamic, aspartic, serine, valine and leucine $(12.9,9.1,9.8,6.8$ and $7.7 \%$, respectively). The content of the hydrophobic amino acids residues (proline, valine, isoleucine, leucine and phenyl alanine) is $27.8 \%$ and this represent $31.1 \%$ of the total amino acids.

Fourier transform infrared (FTIR) spectroscopy

One of the classical methods for structure determination of small molecules is IR. This standing is due to its sensitivity to the chemical composition and architecture of molecules. The high information content in an infrared spectrum carries over also to biological systems. This makes infrared spectroscopy a valuable tool for the investigation of protein structure (Arrondo et al., 1993; Barth, 2007) of the molecular mechanism of protein reactions (McClelland $\boldsymbol{e t}$ al., 2002) and of protein folding, unfolding and misfolding (Pozo Ramajo et al., 2005). In order to study proteins, the analysis of the secondary structure of protein is often required by FTIR in recent years. FTIR spectroscopy has been proven to be a powerful tool for providing conformational and structural dynamic information of proteins. FTIR spectra of the lectin isolated from wheat seeds was shown in Fig. 3.

The infrared analysis indicated the presence of glycosylation with two typical carbohydrate absorptions at $3000-2800 \mathrm{~cm}^{-1}$ and $1400-1200$ $\mathrm{cm}^{-1}$. The secondary structure of the protein were commonly based on the amide I band analysis $\left(1700-1600 \mathrm{~cm}^{-1}\right)$. Amide I band peaks identified are more mature. It is the most intense absorption band of the polypeptides. $v(\mathrm{C}=\mathrm{O})$ has a predominant role in amide $\mathrm{I}, v(\mathrm{C}-\mathrm{N})$ follows. There is also some in-plane $\mathrm{NH}$ bending contribution to amide I. The secondary structure of proteins is reflected by these bands as follows: $1610 \sim 1640 \mathrm{~cm}^{-1}$ for the $\beta$-sheet; $1640 \sim 1650 \mathrm{~cm}^{-1}$ for the random coil; $1650 \sim$ $1658 \mathrm{~cm}^{-1}$ for the $\alpha$-helix; $1660 \sim 1700 \mathrm{~cm}^{-1}$ for the $\beta$-turn. These results agree with those reported by (Wang et al., 2018).

\section{Antibacterial Activity of Lectin Against Gram Positive and Gram Negative Bacteria}

Some plant lectins have been studied for their interactions with bacteria (Santi-Gadelha et al., 2006). Some studies with lectin showed its antibacterial activity (Ayouba et al., 1991). Binding of lectins to muramic acid and Nacetylmuramic acid, carbohydrates present in the bacterial cell wall, has been reported earlier (Caldeon et al., 1997). The antibacterial activity of wheat seeds lectin was examined at different concentrations $(200,400,800,1600,3200$ and $6400 \mu \mathrm{g} / \mathrm{ml}$ ) and the results are listed in Table 2 and Fig 4. The minimum inhibitory concentration (MIC) of lectin against $L$. monocytogenes and $P$. aeruginosa was $800 \mu \mathrm{g} / \mathrm{ml}, 1600 \mu \mathrm{g} / \mathrm{ml}$ for $B$. subtillis and $3200 \mu \mathrm{g} / \mathrm{ml}$ against $E$. coli. These results agree with those reported by (Saha $\boldsymbol{e t}$ al., 2014). The antibacterial activity of lectin isolated from wheat seeds may be due to the hydrophobic amino acid residues. The content of the hydrophobic amino acids residues (proline, valine, isoleucine, leucine, and phenylalanine) is $27.8 \%$ and this represents $31.2 \%$ of the total amino acids. Protein hydrophobicity plays an important role in the disturbance of the bacterial cell wall and membrane (Abdel-Hamid $\boldsymbol{e t}$ al., 2016).

\section{Antifungal Activity of Lectin}

The in vitro antifungal activities of wheat seeds lectin (Fig. 5) against $F$. oxysporun and $F$. solani were examined at different concentrations 
Zagazig J. Agric. Res., Vol. 46 No. (3) 2019

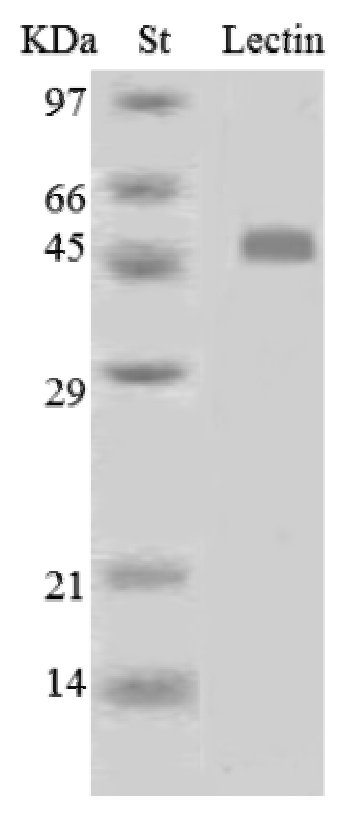

Native-PAGE

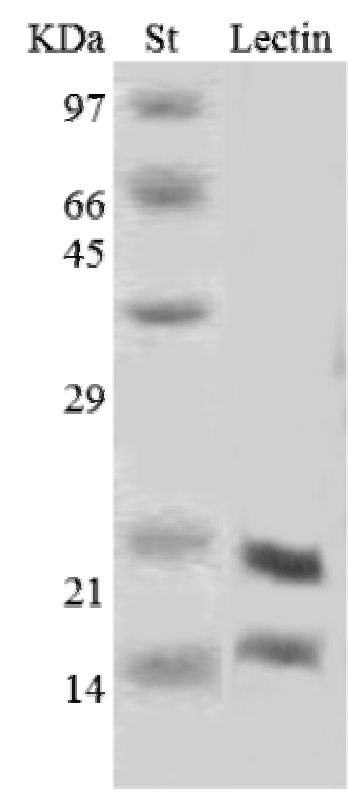

SDS-PAGE

Fig. 1. Native-PAGE and SDS-PAGE of lectin isolated from wheat seeds cultivar Giza 171 as compared to standard protein $(\mathrm{St})$

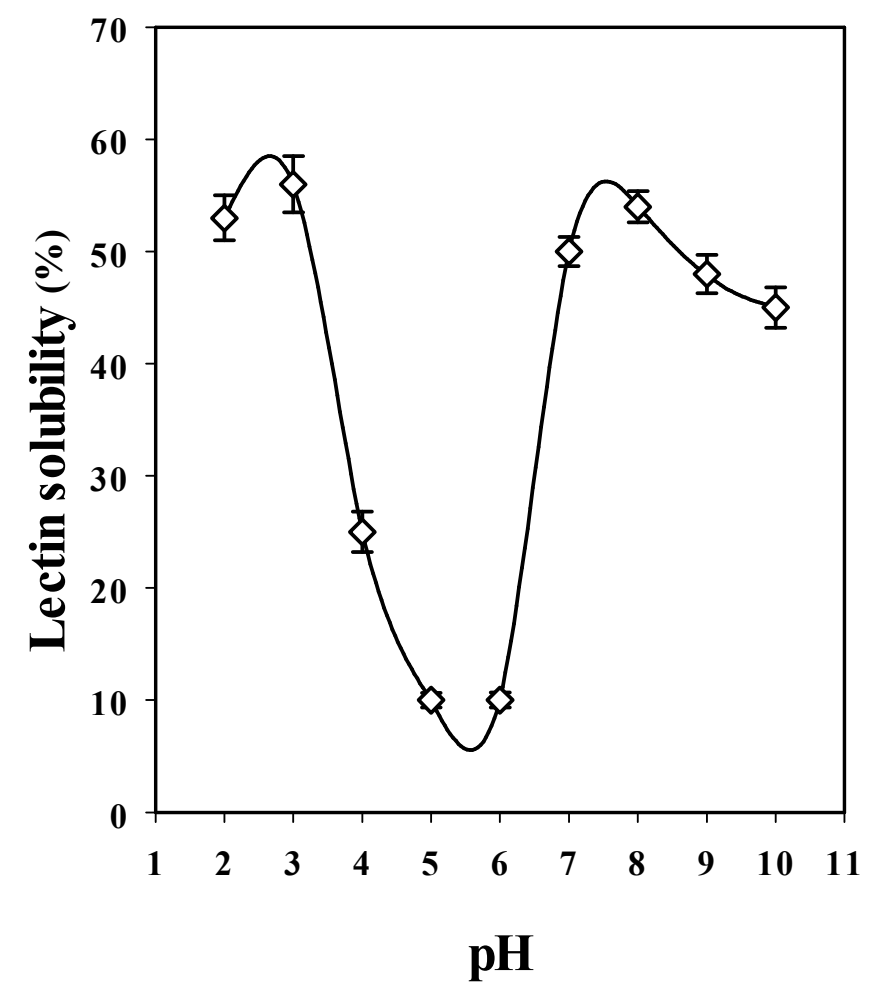

Fig 2. pH solubility curve of wheat seeds lectins at different pH from 2 to 10 
Table 1. Amino acids composition of wheat seeds lectin

\begin{tabular}{lc}
\hline Amino acid & Percentage (\%) \\
\hline Aspartic & 7.1 \\
Threonine & 9.8 \\
Serine & 12.9 \\
Glutamic & 3.5 \\
Proline & 1.4 \\
Cysteine & 6.8 \\
Valine & 4.9 \\
Methionine & 4 \\
Isoleucine & 7.7 \\
Leucine & 3.3 \\
Tyrosine & 5.8 \\
Phenylalanine & 4.3 \\
Histidine & 5.9 \\
Lysine & 3.1 \\
Arginine & 10.5 \\
Unknowns & \\
\hline
\end{tabular}

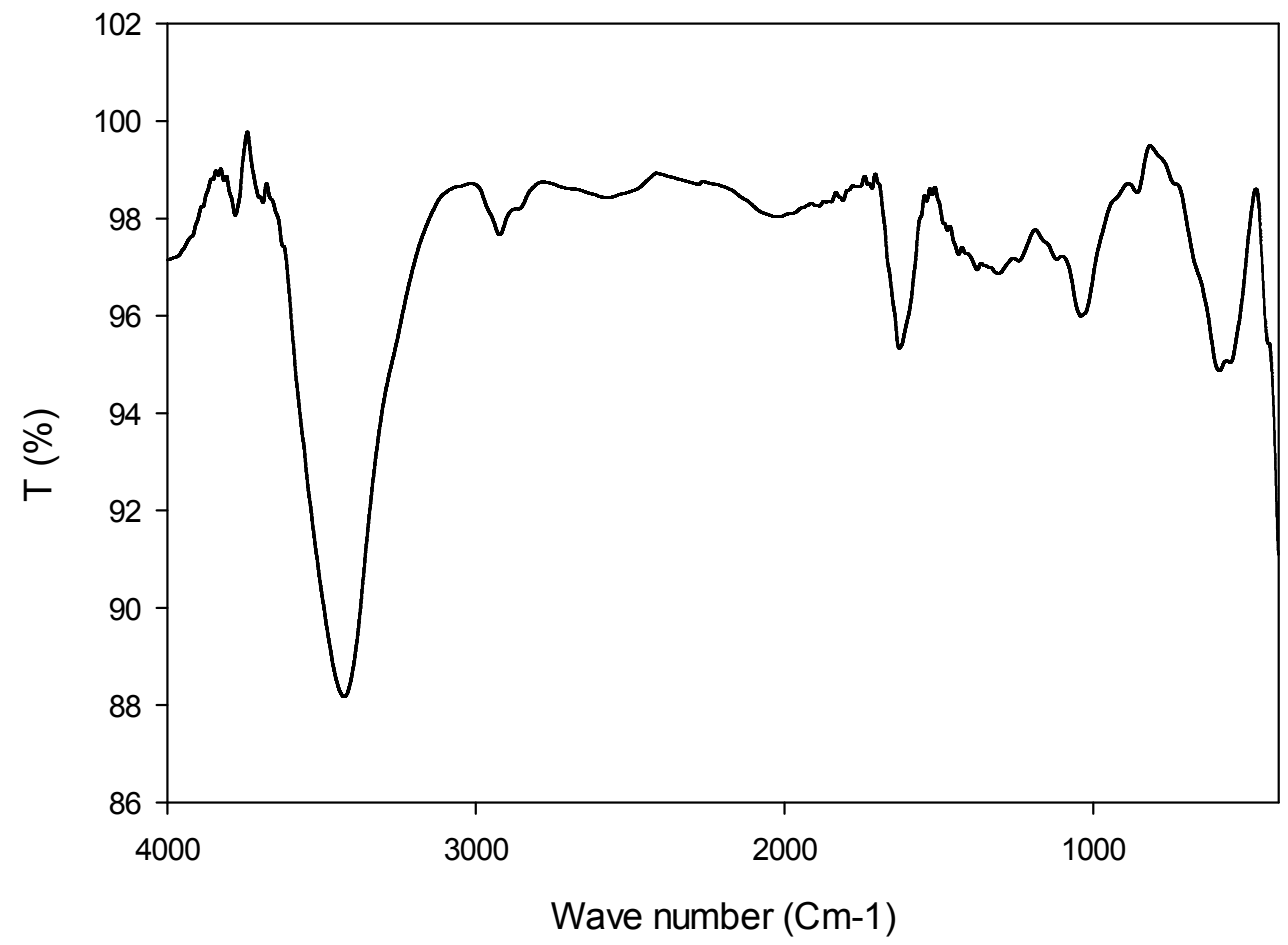

Fig. 3. FTIR spectra of lectin isolated from wheat seeds 
Gram positive bacteria

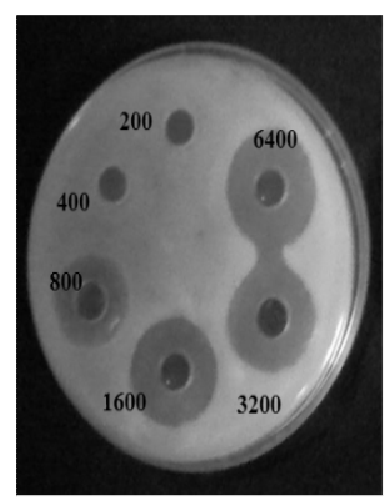

L. monocytogens

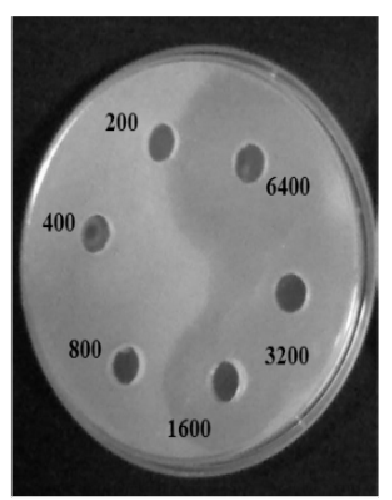

B. subtillis

Gram negative bacteria

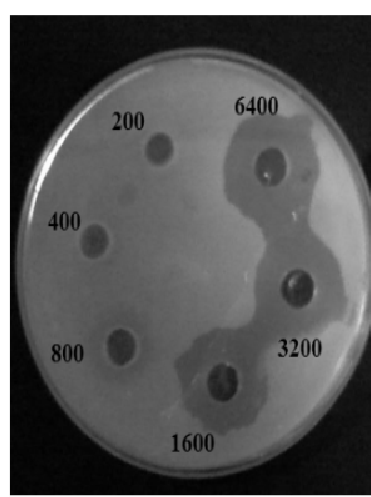

P. aerugenosa

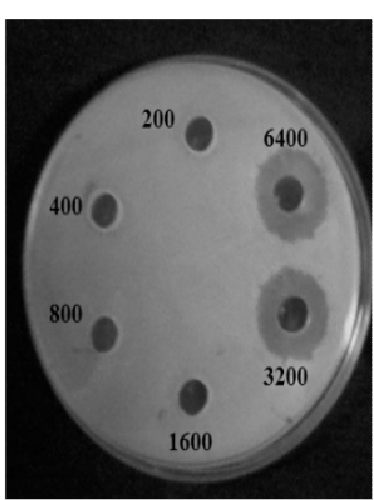

E. coli

Fig. 4. The size $(\mathrm{mm})$ of inhibition zones induced in Gram+ and Gram- bacteria under the influence of different concentrations (200-6400 $\left.\mathrm{g} \mathrm{m}^{-1}\right)$ of wheat seeds lectin using agar well diffusion assay

Table 2. The size $(\mathrm{mm})$ of inhibition zones induced in Gram+ and Gram- bacteria under the influence of different concentrations $\left(200-6400 \mu \mathrm{g} \mathrm{ml}^{-1}\right)$ of wheat seeds lectin using agar well diffusion assay

\begin{tabular}{lcccccc}
\hline Microorganism & \multicolumn{5}{c}{ Lectin concentration $\left(\boldsymbol{\mu g} \mathbf{~ m l}^{-1}\right)$} \\
\cline { 2 - 6 } & $\mathbf{2 0 0}$ & $\mathbf{4 0 0}$ & $\mathbf{8 0 0}$ & $\mathbf{1 6 0 0}$ & $\mathbf{3 2 0 0}$ & $\mathbf{6 4 0 0}$ \\
\cline { 2 - 6 } & \multicolumn{5}{c}{ Inhibition zone diameter $(\mathbf{m m})^{\text {Gram }^{+}}$} \\
L. monocytogens & - & - & 15 & 20 & 22 & 26 \\
B. subtilis & - & - & - & 33 & 35 & 48 \\
& - & - & Gram $^{-}$ & & & \\
P. aerugenosa & - & - & 10 & 18 & 21 & 24 \\
E. coli & - & - & - & - & 15 & 17 \\
\hline
\end{tabular}




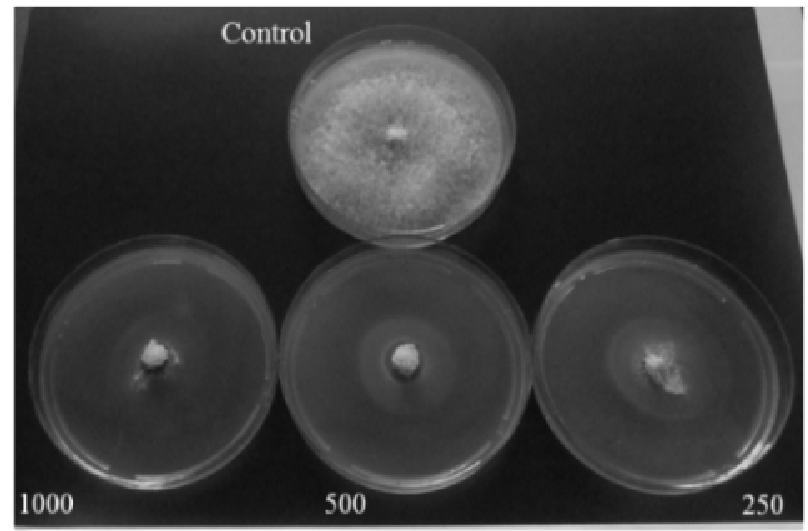

Fusarium oxysporum

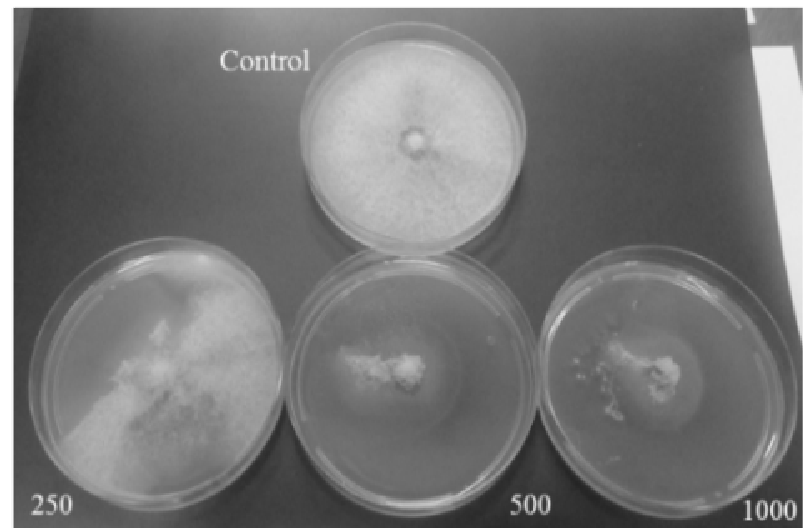

Fusarium solani

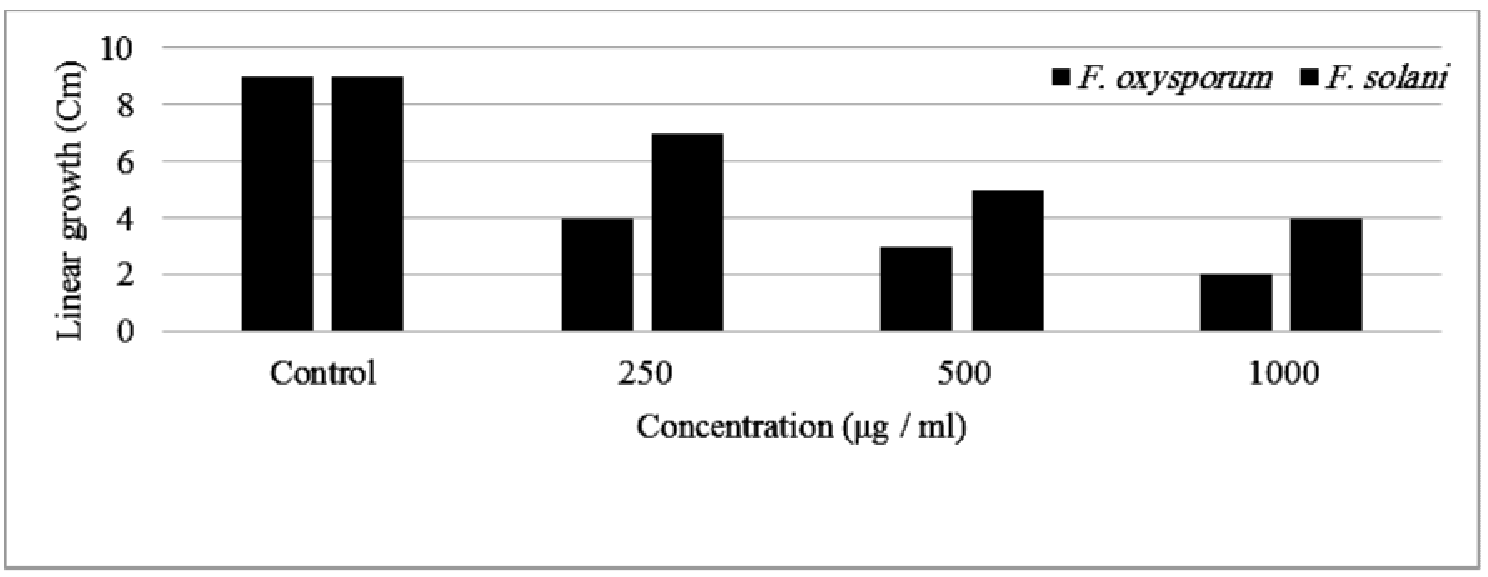

Fig. 5. Linear growth (cm) of Fusarium oxysporum and Fusarium solani after 7 days at $25^{\circ} \mathrm{C}$ in the presence of wheat seed lectin at different concentrations $(250,500$ and $1000 \mu \mathrm{g} / \mathrm{ml})$

$(250,500$ and $1000 \mu \mathrm{g} / \mathrm{ml})$. Lectin inhibited mycelial growth at a wide concentration range $(250,500$ and $1000 \mu \mathrm{g} / \mathrm{ml})$. On the other hand, lectin showed a concentration-dependent inhibitory action on the fungal growth. Some studies with lectin isolated from different sources showed its antifungal activity against pathogenic fungal species ( Maria das Graças et al., 2002; Yan et al., 2005; Tian et al., 2008; Chen et al., 2009; Kheeree et al., 2010).

\section{REFERENCES}

Abdel-Hamid, M., H.A. Goda, C. De Gobba, H. Jenssen and A. Osman (2016). Antibacterial activity of papain hydrolysed camel whey and its fractions. Int. Dairy J., 61:91-98.

Arrondo, J.L.R., A. Muga, J. Castresana and F.M. Goñi (1993). Quantitative studies of the structure of proteins in solution by Fouriertransform infrared spectroscopy. Progress in Biophysics and Molecular Biol., 59:23-56.

Ayouba, A., C. Chatelain and P. Rougé (1991). Legume lectins interact with muramic acid and $\mathrm{N}$-acetylmuramic acid. FEBS letters, 289: 102-104.

Barth, A. (2007). Infrared spectroscopy of proteins. Biochimica et Biophysica Acta (BBA)-Bioenergetics, 1767:1073-1101.

Caldeon, A., G. Buck and R. Doyle (1997). Lectin-microorganism complexes. Electronic Lectin J.: Lectins, Biol. Biochem., Clinical Biochem., 12:87-984583.

Chen, J., B. Liu and N. Ji (2009). A novel sialic acid-specific lectin from Phaseolus coccineus seeds with potent antineoplastic and antifungal activities. Phytomed., 16:352-360. 
Chobert, J-M., A. Touati, C. Bertrand-Harb, M. Dalgalarrondo, M-G. Nicolas and T. Haertle (1991). In vitro proteolysis and functional properties of reductively alkylated $\beta$-casein derivatives. J. Dairy Res., 58:285-298.

Hafidh, R.R., F. Abas, A.S. Abdulamir, F. Jahanshiri, F.A. Bakar and Z. Sekawi (2009). A review: Cancer research of natural products in Asia. Int. J. Cancer Res., 5:69-82.

Horwitz, W. and G. Latimer (2000). Official Methods of Analysis of AOAC International, Gaithersburg MA, USA. Assoc. Official Anal. Chem.

Karnchanatat, A. (2012). Antimicrobial activity of lectins from plants. Antimicrobial agents. In. Tech., 145-178.

Kheeree, N., P. Sangvanich, S. Puthong and A. Karnchanatat (2010). Antifungal and antiproliferative activities of lectin from the rhizomes of Curcuma amarissima Roscoe. Appl. Biochem. and Biotechnol., 162 : 912925.

Laemmli, U.K. (1970). Cleavage of structural proteins during the assembly of the head of bacteriophage T4. Nat., 227:680-685.

Maria das Graças, M.F., V.M. Gomes and R.E. Corsini (2002). Isolation and partial characterization of a novel lectin from Talisia esculenta seeds that interferes with fungal growth. Plant Physiol. and Biochem., 40: 61-68.

Matucci, A., G. Veneri and C.D. Pellegrina (2004). Temperature-dependent decay of wheat germ agglutinin activity and its implications for food processing and analysis. Food Control, 15: 391-395.

McClelland, J., R. Jones, S. Bajic, J. Chalmers and P. Griffiths (2002) Handbook of Vibrational Spectroscopy. John Wiley and Sons, Ltd.

Mendoza-Blanco, W., L. Ponce-Soto and S. Marangoni (2012). Purification and primary structure of a lectin from Buddleja coriacea seeds. Sciéndo (Trujillo), 15: 81-88.

Nanda, A. and M. Saravanan (2009). Biosynthesis of silver nanoparticles from Staphylococcus aureus and its antimicrobial activity against
MRSA and MRSE. Nanomedicine: Nanotechnol., Biol. and Med., 5 : 452-456.

Pozo Ramajo, A., S.A. Petty, A. Starzyk, S.M. Decatur and M. Volk (2005). The $\alpha$-helix folds more rapidly at the $\mathrm{C}$-terminus than at the N-terminus. J. Ame. Chem. Soc., 127: 13784-13785.

Saha, R.K., S.H.M. Tuhin, N. Jahan, A. Roy and P. Roy (2014). Antibacterial and antioxidant activities of a food lectin isolated from the seeds of Lablab purpureus. Ame. J. Ethnomed., 1: 8-17.

Santi-Gadelha, T., C.A. de Almeida Gadelha and K.S. Aragao (2006) Purification and biological effects of Araucaria angustifolia (Araucariaceae) seed lectin. Biochem. and Biophysical Res. Communications, 350: 1050- 1055.

Siegel, R., J. Ma, Z. Zou and A. Jemal (2014). Cancer statistics, CA: A Cancer J. Clin., 64:9-29.

Simpson, R.J., M.R. Neuberger and T. Liu (1976) Complete amino acid analysis of proteins from a single hydrolysate. J. Biol. Chem., 251: 1936-1940.

Souillac, P.O., C.R. Middaugh and J.H. Rytting (2002). Investigation of protein/carbohydrate interactions in the dried state. 2. Diffuse reflectance FTIR studies. Int. J. Pharm., 235: 207-218.

Surewicz, W.K. and H.H. Mantsch (1988). New insight into protein secondary structure from resolution-enhanced infrared spectra. Biochimica et Biophysica Acta (BBA)Protein Structure and Molecular Enzymol., 952: 115-130.

Thorburn, A. (2008). Apoptosis and autophagy: regulatory connections between two supposedly different processes. Apoptosis, 13: $1-9$.

Tian, Q., W. Wang and C. Miao (2008). Purification, characterization and molecular cloning of a novel mannose-binding lectin from rhizomes of Ophiopogon japonicus with antiviral and antifungal activities. Plant Sci., 175:877-884. 
van Buul, V.J. and F.J. Brouns (2014). Health effects of wheat lectins: A review. J. Cereal Sci., 59 : 112-117.

Wang, Z., A. Tu, D. Tang and Y. Shan (2018). Effectively preparing soluble ovomucin with high antiviral activity from egg white. Int. J. Biol. Macromolecules.

Yahyazadeh, M., R. Zare, R. Omidbaigi, M. Faghih-Nasiri and M. Abbasi (2009). Control of Penicillium decay on citrus fruit using essential oil vapours of thyme or clove inside polyethylene and nano-clay polyethylene films. J. Hort. Sci. and Biotechnol., 84: 403409.

Yan, Q., Z. Jiang, S. Yang, W. Deng and L. Han (2005) A novel homodimeric lectin from Astragalus mongholicus with antifungal activity. Archives of Biochem. and Biophysics, 442:72-81.

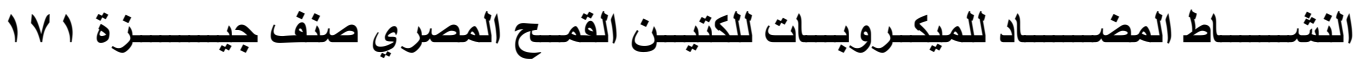 \\ صفا عبدالوهاب مصطقى - هيثم على بلر - على عثمان - خالد محمد وهدان

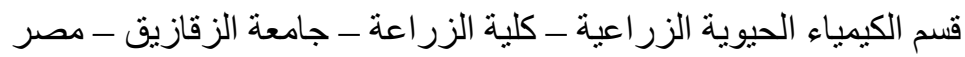

فى هذه الدر اسة تم فصل اللكتين الخام من بذور القمح المصرى صنف جيزة ال اوعمل توصيف كيميائى لله بعدة طرق

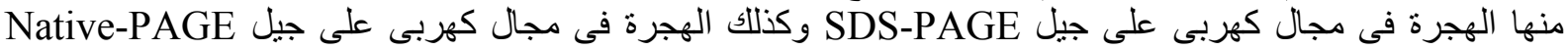

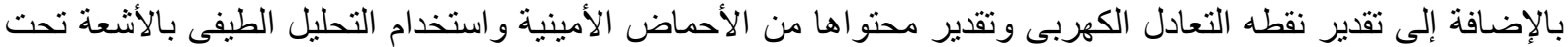

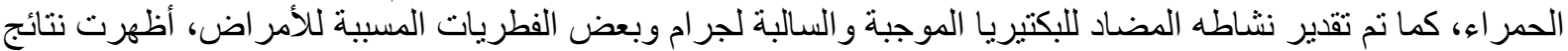

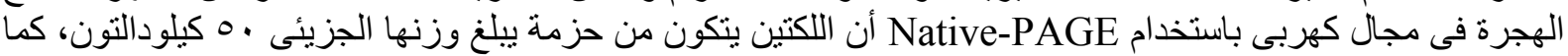

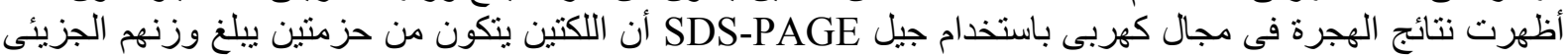

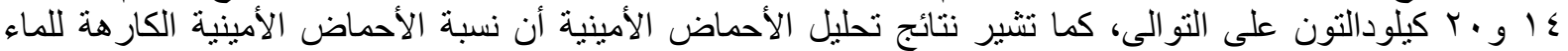

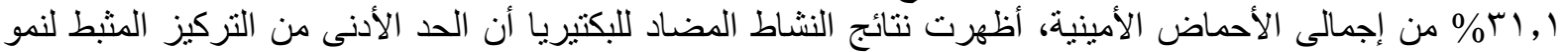

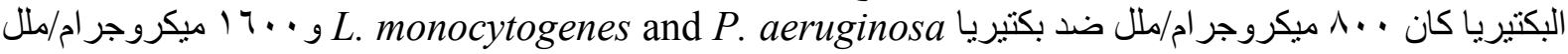

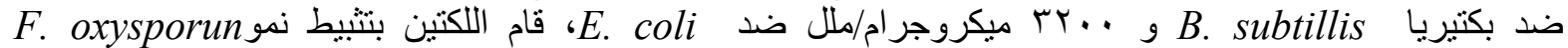

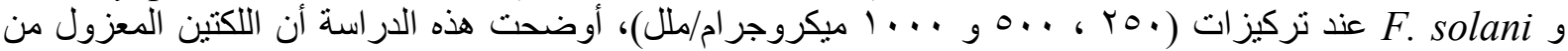

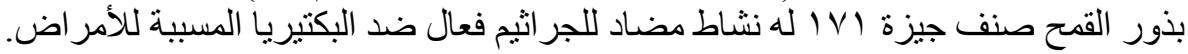

